\title{
Incidence of Misshapen Fruits in Strawberry Plants Grown under Tunnels Is Affected by Cultivar, Planting Date, Pollination, and Low Temperatures
}

\author{
María Teresa Ariza and Carmen Soria \\ IFAPA, Centro de Churriana. Cortijo de la Cruz s/n, 29140 Churriana, \\ Málaga, Spain
}

Juan Jesús Medina-Mínguez

IFAPA, Centro de Las Torres-Tomejil. Ctra. Sevilla-Cazalla Km 12.2, 41200

Alcalá del Río, Sevilla, Spain

Elsa Martínez-Ferri ${ }^{1}$

IFAPA, Centro de Churriana. Cortijo de la Cruz s/n, 29140 Churriana, Málaga, Spain

Additional index words. fruit malformation, berries, cultivation systems, Fragaria $\times$ ananassa, yield

\begin{abstract}
Misshapen fruit represent a significant problem for strawberry (Fragaria $\times$ ananassa Duch.) producers around the world. We investigated the effect of cultivar and different cropping practices on the productivity of strawberry plants growing in tunnels at Huelva (Spain) over three years. In the first experiment, 'Camarosa', 'Ventana', and 'Medina' were planted on 10 or 22 Oct. at standard $(30 \times 25 \mathrm{~cm})$, wide $(35 \times 25 \mathrm{~cm})$, or narrow $(25 \times 25 \mathrm{~cm})$ spacings. In the second experiment, 'Camarosa' was grown in macro- or microtunnels with and without bees. There was no effect of plant density. Planting time resulted in higher early yields in 'Ventana' and higher misshapen fruit in 'Camarosa' with an early compared with a late planting. 'Camarosa' had the lowest yields and the highest incidence of misshapen fruit. More of the early crop was misshaped and this was related to low temperatures in the 7 weeks before harvest. Pollination reduced the incidence of misshapen fruit and increased yield. Plants grown in macrotunnels were only more productive than those grown in microtunnels when they were pollinated by bees. These results demonstrate that the productivity of strawberry plants growing in tunnels can be enhanced by the selection of the appropriate cultivar, planting date, tunnel system, and pollination protocol. The use of macrotunnels with supplementary pollination results in better economic returns by increasing yield and decreasing the incidence of misshapen fruit. In addition, in some cultivars this profit can be enhanced by early planting, which enables early arrival of fruits into the markets at better prices for growers.
\end{abstract}

Misshapen fruit reduce the returns of most commercial strawberry cultivars (Fragaria $\times$ ananassa Duch.) grown under conventional cropping practices. Huelva, Spain, is the main strawberry growing area in Europe

\footnotetext{
Received for publication 3 Apr. 2012. Accepted for publication 13 Sept. 2012.

This research was funded by the RTA2004-008 and CC10-009-C02-02 INIA projects and by FEDER funds. Dra. Ariza was supported by a research grant financed by the "Instituto Nacional de Investigación y Tecnología Agraria y Alimentaria INIA" (Spain).

We are very grateful to two anonymous referees for their valuable comments on a previous draft of the manuscript. We thank Dr. I. Padilla for language editing.

${ }^{1}$ To whom reprint requests should be addressed; e-mail elsa.martinez@juntadeandalucia.es.
}

freezing) on strawberry production and fruit quality can be reduced by using different cultural practices. In this sense, the use of polyethylene plastic tunnels in strawberry production has been widely adopted (Lamont, 2009), providing higher yields compared with field production systems (Faedi and Baruzzi, 2003; López-Aranda, 2008; López-Aranda et al., 2003; Salamé-Donoso et al., 2010). The use of tunnels has an additional benefit by promoting early fruit and therefore allowing growers to produce fruit during the high-value off-season (Salamé-Donoso et al., 2010).

Some producers also use pollinator insects such as bees or bumblebees to improve pollination by increasing mobility of pollen grains and, consequently, ensuring ovule fertilization and achene development (Leech et al., 2000). Pollination by insects often enhances yield and fruit quality compared with non-pollinated crops (Abak et al., 1997; Chagnon et al., 1993; Ercan and Onus, 2003; Kwon and Saeed, 2003; Picken, 1984; Roselino et al., 2009; Zaitoun et al., 2006).

It has been also shown that plant density and the time of planting can influence strawberry production (López-Medina et al., 2001). Higher plant densities can facilitate crosspollination and increase productivity per surface area. Planting early in the season may promote early growth and yield by breaking plant dormancy (Kronenberg and Wassenaar, 1972).

All of these cultural practices might affect the incidence of misshapen fruit by modifying the development of strawberry plants in a specific cropping area (Ito and Saito, 1962; Kumukara and Shishido, 1995; Woon and Michele, 1992).

We investigated the effect of the cultivar and different cropping practices (plant date, plant density, cover system, and use of pollinator bees) on yield and on the occurrence of misshapen fruit in strawberry plants grown under tunnels in Spain over two seasons.

\section{Materials and Methods}

and the second worldwide after the United States (FAOSTAT, 2008); 'Camarosa' is the most important cultivar. Losses resulting from misshapen fruit in this cultivar are $\approx 4 \%$ of production, which is worth about EUR 485 million.

Misshapen fruit are not symmetrically heart-shaped and are usually smaller than "well-formed" fruit (Ariza et al., 2011). The occurrence of misshapen fruit is related to a localized loss of achene functionality resulting from temperatures below $7{ }^{\circ} \mathrm{C}$ during pollen and embryo development (Ariza et al., 2011). Cultivars also vary in the incidence of the disorder (Ariza et al., 2011; Carew et al., 2003). Hence, the occurrence of misshapen fruit depends on the effects of environment and genetics.

The negative impacts of climatic variability (i.e., abrupt changes in temperature and

\section{Site description and agronomy}

Two field experiments were carried out from 2004 to 2006 at the IFAPA experimental station "El Cebollar" at Moguer in Huelva, Spain (lat. $37^{\circ} 16^{\prime} \mathrm{N}$, long. $6^{\circ} 50^{\prime}$ $\mathrm{W}$, alt. $63 \mathrm{~m}$ a.s.1.). This area has a Mediterranean climate with dry, warm summers and moderately cold winters. Mean annual precipitation is $508 \pm 57 \mathrm{~mm}$ (2004-2009) occurring mainly in fall and winter. Average mean temperature is $17.1 \pm 0.8^{\circ} \mathrm{C}$.

Strawberry (Fragaria $\times$ ananassa Duch.) plants were propagated during summer at high-elevation nurseries in Castille-Leon (lat. $41^{\circ} 30^{\prime} \mathrm{N}$, long. $4^{\circ} 55^{\prime} \mathrm{W}$, alt. 900 to $1200 \mathrm{~m}$ a.s.1.) with at least 150 to $200 \mathrm{~h}$ of temperatures below $7{ }^{\circ} \mathrm{C}$ (López-Aranda et al., 2003). Standard agronomy for strawberry production in Huelva was used. In midOctober (22 Oct.) plants were transplanted 
into double-row $(30 \times 25 \mathrm{~cm}$ apart; $\approx 60,000$ plants/ha) mulched raised beds $(35 \mathrm{~cm}$ high and $50 \mathrm{~cm}$ wide) on a sandy soil covered by plastic to conserve water and keep the fruit clean (Kasperbauer, 2000). Before planting, the soil was solarized and biofumigated (biosolarization; Medina-Mínguez et al., 2009) to reduce the incidence of soil pathogens. Most of the strawberry plants at Huelva are grown under plastic tunnels (80\% macrotunnel and 20\% microtunnel; CAP, 2007) to protect the crop from frost and rain during winter and early spring. Polyethylene-covered $(150-\mu \mathrm{m}$ thick plastic) tunnel structures are installed in midNovember and removed in mid-March, in the case of microtunnels, or at the end of the cropping season for macrotunnels. Fruit set takes place from January (midwinter) to the end of May (late spring). Bumblebees are used as pollinators ( 250 to $300 \mathrm{bumblebees} / \mathrm{ha}$ ) to improve fruit fertilization under macrotunnels. The plants received: $175 \mathrm{~kg}$ nitrogen $/ \mathrm{ha}$, $77 \mathrm{~kg}$ phosphorus/ha, $185 \mathrm{~kg}$ potassium/ha, $85 \mathrm{~kg}$ calcium/ha, and $14 \mathrm{~kg}$ magnesium $/ \mathrm{ha}$ between mid-November and mid-May through the irrigation.

Expt. 1: Effect of planting date, plant density, and cultivar on yield and the incidence of misshapen fruit. In 2004, an experiment was conducted to evaluate the effect of different planting dates $\left(\mathrm{P}_{\text {Date }}\right)$ and plant densities $\left(\mathrm{P}_{\text {Density }}\right)$ on the performance of 'Camarosa' (Larson, 2001), 'Ventana' (Larson, 2001), and 'Medina' (López-Aranda et al., 2005). The plants were planted on 10 or 22 Oct. at standard $(30 \times 25 \mathrm{~cm})$, wide $(35 \times 25 \mathrm{~cm})$, or narrow $(25 \times 25 \mathrm{~cm})$ plant spacings. Plants were planted under a polyethylenecovered macrotunnel structure $(25 \mathrm{~m}$ long $\times$ $6.6 \mathrm{~m}$ wide $\times 3 \mathrm{~m}$ high) in a split-split plot design with three replicate plots and 50 plants per plot. The different planting dates were in the main plots, the different planting densities were in the split plots, and the different cultivars in the split-split plots. From January to May, all mature fruit on each plot were harvested once or twice a week and separated into well-formed and marketable fruit (WF) and misshapen fruit (MF). There was no additional non-marketable fruit. Total yield (i.e., sum of WF and MF fruits; g/plant) and the percentage of misshapen fruit [MF (\%)] were calculated for the entire season as well as for early (January to March) and late (April to May) season. Marketable fruit yield can be easily calculated by multiplying total yield by [1-MF (\%)].

Temperatures under the tunnel were recorded using one Escort Mini data logger (Escort Data Logging Systems Ltd., New Zealand).

Expt. 2: Effect of tunnel structure and the use of pollinators on yield and the incidence of misshapen fruit. In 2005 and 2006, an experiment was carried out at the same site as in Expt. 1 to evaluate the effect of the cover structure and the use of pollinator insects on the performance of 'Camarosa'. Plants were grown in macro- $(25 \mathrm{~m}$ long $\times 6.6 \mathrm{~m}$ wide $\times$ $3 \mathrm{~m}$ high) or microtunnels $(20 \mathrm{~m}$ long $\times 0.6 \mathrm{~m}$ wide $\times 0.4 \mathrm{~m}$ high) with or without bumblebees (Bombus terrestris L.). Plants in the different plots were isolated from neighboring plots by the use of insect-proof mesh. Approximately 250 to 300 bumblebees/ha were released under the mesh for pollination. Data on yield (g/plant) and the incidence of MF were collected as described previously.

The experiment was setup in a split plot design with three replicate plots and 80 plants per plot spaced at $30 \times 25 \mathrm{~cm}$. The different tunnels were in the main plot and the presence or absence of pollinator in the subplots.

Temperature and relative humidity under each tunnel were recorded every $15 \mathrm{~min}$. These data were used to assess the relationship between the incidence of misshapen fruit and environmental conditions.

\section{Statistical analysis}

Data were analyzed using the analytical software STATISTIX 9.0 (Analytical Software, FL). Before analysis of variance (ANOVA), normality and homogeneity assumptions were tested by using the Kolmogorov-Smirnov and Cochran's C tests, respectively. In Expt. 1, data on yield and on the incidence of MF on each harvesting period were evaluated by a split-split plot ANOVA (two planting dates $X$ three plant spacing $X$ three cultivars). In Expt. 2, data on yield and on the incidence of MF for the entire season or for the two harvesting periods separately were analyzed by a split-plot ANOVA (two tunnels $x$ two pollinators). For comparisons between years and harvesting periods, data on total yield and on the incidence of MF were subjected to a repeated-measures ANOVA (ANOVAR). In this model "year" and "period" were the within subject factor. For assessing the interaction between harvesting period and the use of pollinators, in the ANOVAR model, "Pollinator" was introduced as a betweensubjects factor. A series of one-way ANOVAs were used to assess the differences in environmental variables under the different tunnels during the two harvest periods. Differences at the $5 \%$ probability level were considered significant and Fisher's least significant difference (LSD) test was used to compare means.

Pearson's correlations and stepwise lineal regressions were performed with the STATISTICA 7.0 (StatSoft Inc.) analytical software for assessing the relationship between the variation of environmental variables under the tunnel structures and the incidence of MF. For correlations with environmental variables, we only considered weekly averaged data of MF recorded on the three plots of each tunnel structure and from the "without" pollinator treatment. Because it has been reported that fruit malformation is closely related to the low temperatures during flower and fruit development (Ariza et al., 2011), regressions were made with average minimal temperatures on the week of harvesting and from 1 to 9 weeks before harvesting ( $\mathrm{T}_{\min 0}$, $\mathrm{T}_{\min -1}, \ldots \mathrm{T}_{\min -9}$, respectively).
For the analysis of the data expressed as percentages (i.e., MF), a mean value $(\mathrm{P} \%)$ was calculated for each plot and an arsine transformation was used \{i.e., arsine $[\operatorname{sqrt}(\mathrm{P} \%) / 100]\}$ to normalize treatment means. However, for convenience, data of MF presented in tables and figures are back-transformed means.

\section{Results}

Effect of planting date, plant density, and cultivar on yield and on the incidence of misshapen fruit. During the study, mean maximum and minimum temperatures under the tunnels were $27.5 \pm 0.5^{\circ} \mathrm{C}$ and $8.7 \pm$ $0.3{ }^{\circ} \mathrm{C}$, respectively, with an absolute maximum of $39.5^{\circ} \mathrm{C}$ and an absolute minimum of $0.5^{\circ} \mathrm{C}$.

Yield over the entire season was higher in 'Medina' (1156 $\pm 33 \mathrm{~g} /$ plant), intermediate in 'Ventana' (1023 $\pm 34 \mathrm{~g} /$ plant), and lower in 'Camarosa' ( $887 \pm 43 \mathrm{~g} /$ plant) (LSD critical T-value 2.064; $P<0.05)$. In contrast, there was no significant $(P>0.05)$ effect of " $P_{\text {Date }}$ " or "P $P_{\text {Density" on yield over any period. The only }}$ exception to this was in 'Medina', which had higher early yields (up to $30 \%$ compared with the standard planting date) when planted early (Fig. 1A). Results were similar when marketable fruit yield was analyzed separately (data not shown).

Most of the misshapen fruit occurred early in the season (Fig. 1B). The incidence of the disorder was higher in 'Camarosa' than in the other two cultivars and higher with the early planting (Fig. 1B). In contrast, planting density had no significant $(P>0.05)$ effect on the incidence of the disorder (data not presented).

Effect of the tunnel structure and the use of pollinating insects on yield and the incidence of misshapen fruit. It was 1 to $2{ }^{\circ} \mathrm{C}$ warmer under the macro- compared with conditions under the microtunnel (Table 1). It was also slightly drier under the macrotunnel.

Yield over the entire season was similar in 2005 than in $2006(P>0.05)$. Yield was equally shifted between the two harvesting periods (data not shown). Yields were higher with pollination than without $(P<0.001)$ but there were no significant $(P>0.05)$ differences between the two types of tunnels (Fig. 2A). However, a significant interaction $(P<0.05)$ between "Pollinator" and "Type of Tunnel" was detected. Yield was higher in the macrotunnel than in the microtunnel with pollination, but yield did not differ between the tunnels in absence of pollinators (Fig. 2A). Results were similar when marketable fruit yield was analyzed separately (data not shown).

The incidence of MF was similar over the two years and higher early in the season than later in the season (Table 2). The use of pollinator insects decreased the incidence of the disorder (Fig. 2B) and this effect was greater early in the season than later in the season $(P<0.05$; Table 2$)$. No significant effects of the "Type of Tunnel" were found on the $\% \mathrm{MF}$ with average values for the 

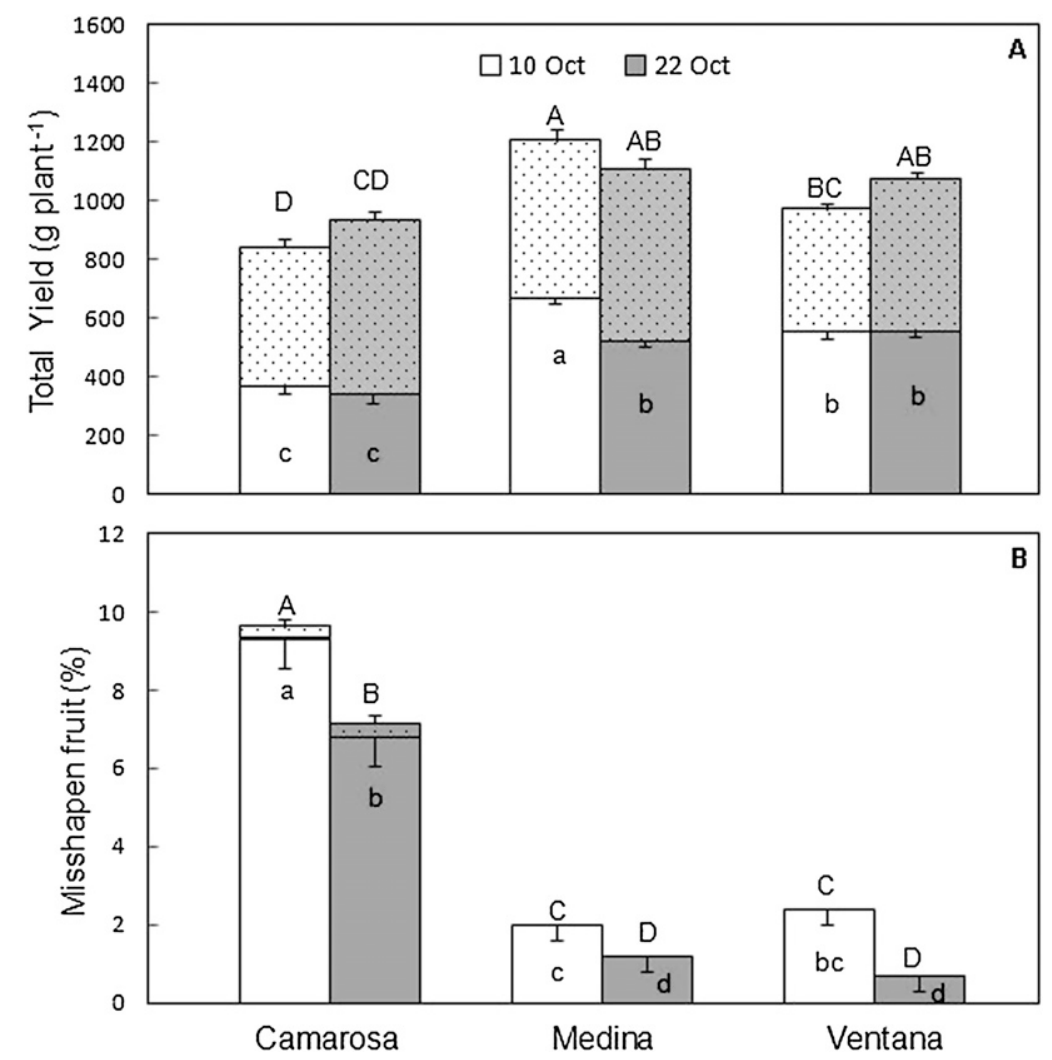

Fig. 1. The effect of planting date on the total yield (A) and incidence of misshapen fruit (B) in three strawberry cultivars grown in tunnels in Huelva, Spain, in 2004. The plants were planted on 10 or 22 Oct. Total yield over the entire season, total early yield from January to March (plain bars), and total late yield from April to May (dotted bars) are shown. Data are the means $\pm \mathrm{SE}$ of nine replicates pooled across three plant densities. Total yield over the entire season means and total early yield means followed by different upper and lower cases letters are significantly different $(P<0.05)$.

Table 1. Average minimum and mean temperatures $\left(T_{\min }\right.$ and $T_{\text {mean }}$, respectively) and mean relative humidity $\left(\mathrm{RH}_{\text {mean }}\right)$ under macro- and microtunnels in the experiments with strawberry plants grown in Huelva, Spain, in 2005 and 2006.

\begin{tabular}{|c|c|c|c|c|}
\hline & \multicolumn{2}{|c|}{2005} & \multicolumn{2}{|c|}{2006} \\
\hline & Macrotunnel $^{\mathrm{z}}$ & Microtunnel & Macrotunnel & Microtunnel \\
\hline \multicolumn{5}{|l|}{$\overline{\mathrm{T}_{\min }\left({ }^{\circ} \mathrm{C}\right)}$} \\
\hline January to March $^{\mathrm{x}}$ & $6.2 \pm 0.5 \mathrm{a}^{y}$ & $5.0 \pm 0.5 \mathrm{~b}$ & $7.9 \pm 0.3 \mathrm{a}$ & $6.7 \pm 0.4 \mathrm{~b}$ \\
\hline April to May & $12.7 \pm 0.3 \mathrm{a}$ & $12.1 \pm 0.3 \mathrm{~b}$ & $13.8 \pm 0.3 \mathrm{a}$ & $12.5 \pm 0.3 \mathrm{~b}$ \\
\hline \multicolumn{5}{|l|}{$\mathrm{T}_{\text {mean }}\left({ }^{\circ} \mathrm{C}\right)$} \\
\hline January to March & $12.4 \pm 0.4 \mathrm{a}$ & $11.3 \pm 0.4 \mathrm{~b}$ & $13.3 \pm 0.3 \mathrm{a}$ & $12.2 \pm 0.3 \mathrm{~b}$ \\
\hline April to May & $20.2 \pm 0.3 \mathrm{a}$ & $18.7 \pm 0.3 \mathrm{~b}$ & $20.7 \pm 0.3 \mathrm{a}$ & $18.8 \pm 0.3 b$ \\
\hline \multicolumn{5}{|l|}{$\mathrm{RH}_{\text {mean }}(\%)$} \\
\hline January to March & $73.5 \pm 1.1 \mathrm{a}$ & $74.8 \pm 1.1 \mathrm{a}$ & $77.9 \pm 0.7 b$ & $80.4 \pm 0.7 a$ \\
\hline April to May & $65.8 \pm 1.1 \mathrm{~b}$ & $72.2 \pm 1.1 \mathrm{a}$ & $68.6 \pm 1.3 \mathrm{~b}$ & $68.8 \pm 2.0 \mathrm{a}$ \\
\hline
\end{tabular}

${ }^{2}$ Each value represents the mean $\pm \mathrm{SE}(\mathrm{n}=60$ to 80$)$.

${ }^{\mathrm{y} B e t w e e n}$ tunnels different letters indicate significant differences at $P<0.05$ (one-way analysis of variance followed by least significant difference test).

January to March = early; April to May = late.

entire season of $26.0 \% \pm 3.0 \%$ and $31.0 \% \pm$ $2.9 \%$ for the macro- and microtunnel, respectively. However, with pollinators, the incidence of MF was significantly higher $(P<0.05)$ in the macro- than in the microtunnel, whereas it did not differ in the absence of pollinators (Fig. 2B).

There was a strong relationship between the incidence of MF and minimum temperature $\left(\mathrm{T}_{\min }\right)$ in the 7 weeks before the fruit were harvested $\left(\mathrm{T}_{\min -7} ; \mathrm{F}_{(1,44)}=33.8 ; P<\right.$ 0.001 ; Fig. 3). The incidence of the disorder temperatures during winter. The extent of the incidence of the disorder depends on the susceptibility of the cultivar to low temperatures, which is probably the result of insufficient chilling hours for cold hardening at the nursery. Cross-pollination by bumblebees reduces the incidence of misshapen fruit under hightunnel structures but does not eliminate it completely.

Effects of different cropping conditions on total yield. The most important factors influencing yield were cultivar, tunnel system, and pollination. Fruit production was higher in 'Medina' than in 'Ventana' and 'Camarosa' and unaffected by planting date or by planting density. Overall, the cultivars were relatively productive compared with yields in commercial fields in this area. In 'Medina', planting early in the season resulted in higher early yields compared with the standard planting. Previous studies have reported differences in early and total extraclass (i.e., first category marketable fruit yield) production either per hectare or per plant among strawberry cultivars at different planting dates or plant densities (López-Medina et al., 2001; Turemis et al., 1996). 'Camarosa' growing under microtunnels opened in warm days to enhance pollination and performed better when planted early and at high plant densities (López-Medina et al., 2001). Our results in 'Camarosa' apparently are in contrast to that but differences may be the result of the experimental setup. Thus, we have evaluated total yield per plant, which includes all marketable fruit yield and misshapen fruit, and our plants were grown under high tunnels with bumblebees as pollinators.

'Camarosa' had the highest yields when pollinators were released under macrotunnels ( $\approx 32 \%$ greater than in microtunnels with pollinator), which are the most common cropping conditions in southwestern Spain. Bumblebees facilitate cross-pollination, which is essential for fruit development in strawberry plants (Albano et al., 2009; Paydas et al., 2000). Similar results have been reported using stingless bees as pollinators for strawberry plants in greenhouses (Malagodi-Braga and Kleinert, 2004; Roselino et al., 2009). The differences in total yield between the two tunnels with pollinators indicate some impediment of insect movement in the microtunnels.

Effects of different cropping conditions on the incidence of misshapen fruit. The incidence of misshapen fruit was higher early in the season, when low temperatures occur concomitantly, and was influenced by the cultivar, the use of pollinators, and the time of planting. 'Camarosa' was more affected than 'Medina' and 'Ventana', especially early in the season, suggesting it is susceptible to low temperatures during flower and fruit development. These results agree with those reported by Ariza et al. (2011) for 'Camarosa', where the achenes failed under low temperatures. In our experiments, minimum temperatures under the tunnel structures still fell below $7^{\circ} \mathrm{C}$ early in the season. Minimum temperatures in the 7 weeks before the fruit are harvested appear to have a decisive influence 


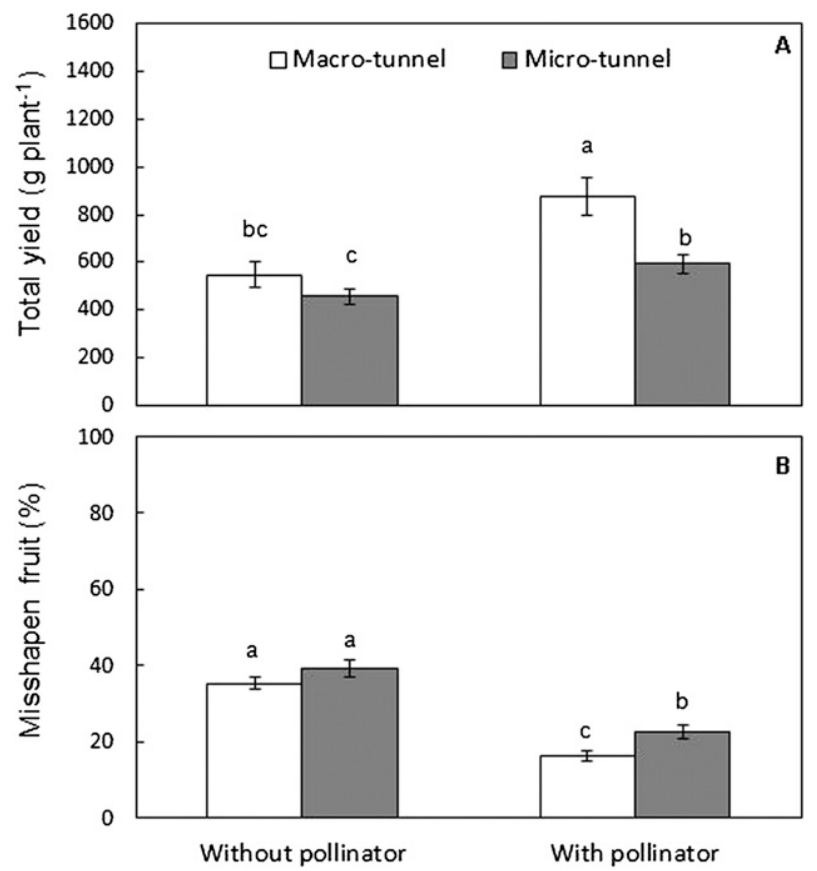

Fig. 2. Effect of tunnel structures and pollination on total yield over the entire season (A) and incidence of misshapen fruit (B) in 'Camarosa' strawberry plants grown in Huelva, Spain, in 2005 and 2006. The plants were grown in micro- or macrotunnels with or without pollination by bees. Data are the means \pm SE of six replicates pooled over the two years. Means followed by different letters are significantly different $(P<0.05)$.

Table 2. The effects of pollination with bumblebees on the incidence of misshapen fruit in 'Camarosa' strawberry plants grown in tunnels in Huelva, Spain, during the two main harvesting periods.

\begin{tabular}{lcc}
\hline & Without pollinator $^{z}$ & With pollinator \\
\hline January to March & $61.3 \pm 3.8 \mathrm{a}^{\mathrm{x}}$ & $25.7 \pm 2.3 \mathrm{~b}$ \\
April to May & $20.3 \pm 1.9 \mathrm{~b}$ & $13.4 \pm 2.8 \mathrm{~b}$ \\
\hline
\end{tabular}

${ }^{\mathrm{z}}$ Values are the means $\pm \mathrm{SE}(\mathrm{n}=12)$ of pooled data from 2005 and 2006 crop seasons in the two tunnels (macro- and microtunnel).

y January to March = early; April to May = late.

${ }^{x}$ Means followed by different letters are significantly different $(P<0.05)$.

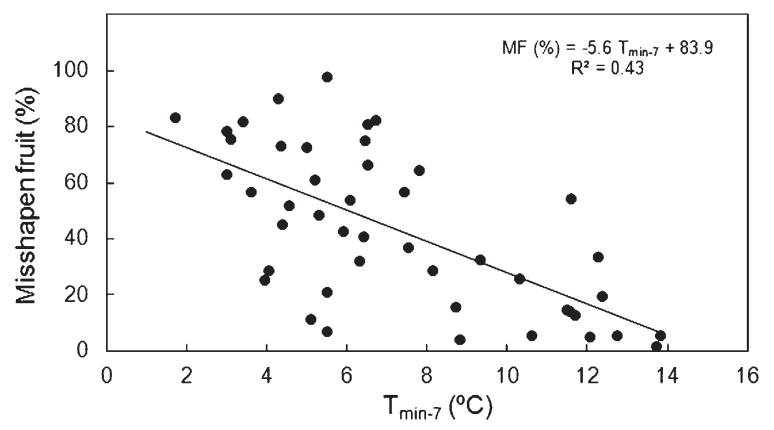

Fig. 3. Relationship between the percentage of misshapen fruit in 'Camarosa' strawberry plants and weekly average minimum temperatures 7 weeks before harvesting $\left(T_{\min -7}\right)$. The plants were grown in macro- and microtunnels without pollinator insects in Huelva, Spain, in 2005 and 2006. Data are the weekly means \pm SE of tree replicates pooled over the two years $(\mathrm{N}=46)$.

on the incidence of misshapen fruit. It would affect early flower developmental stages, because in 'Camarosa', it takes $\approx 40$ to $49 \mathrm{~d}$ to go from anthesis to red fruit (i.e., time to ripening Kano and Asahira, 1981; Perkins-Veazie and Huber, 1987) in the early season (Ariza et al., 2011).

In the absence of pollinators, most of the flowers are self-pollinated and this gives rise to poor quality fruit (Malagodi-Braga, 2002). Cross-pollination by bumblebees reduces the incidence of misshapen fruit (up to $\approx 50 \%$ ) in both types of tunnels, even at low temperatures (Del Pino, 1998). However, pollinators cannot completely eliminate the disorder.

On the other hand, the higher incidence of misshapen fruit when strawberry cultivars were planted early is suggesting a loss of flower and/or fruit quality when shortening the cold-hardening dormancy period at the nursery (Carew et al., 2003; García-Méndez et al., 2008; Kronenberg and Wassenaar, 1972). In fact, a low fruit quality has been associated with poor stamen and pollen quality (Lieten, 1997), which in turn is closely related to the incidence of misshapen fruit in 'Camarosa' (Ariza et al., 2011). In this cultivar, the higher amount of MF even at a standard planting date is suggesting higher chilling requirements to ensure proper flower and fruit development, which would explain its susceptibility to low temperatures along the cropping season.

Relationship between yield and the incidence of misshapen fruit. The effect of cultivar and cropping conditions on yield and the incidence of MF was not always related. Compared with the other two cultivars, low yields in 'Camarosa' were consistently associated with a higher incidence of misshapen fruit. In contrast, in two out of the three cultivars, early yields were similar between planting dates but incidence of misshapen fruit was not. Early planting in 'Medina' resulted in the highest early yields concomitantly with the highest incidence of MF. These results suggest that yield and the development of misshapen fruit are affected by different processes.

\section{Conclusion}

Misshapen fruit mainly appear early in the season, when prices are high $(\approx 2.5$ times higher for early than for late fruit). Thus, any factor that can increase yield and/or fruit quality at this time would enhance returns for growers. The use of macrotunnels with supplementary pollination results in better economic returns by increasing yield and decreasing the incidence of misshapen fruit in strawberry. This is especially recommended in cultivars that are more susceptible to the disorder such as 'Camarosa', in which important savings (up to EUR 18 million) for the strawberry industry can be achieved by reducing substantially the incidence of misshapen fruit in the early season. In cultivars that are less susceptible to the disorder and with greater overall returns such as 'Ventana' and 'Medina', this profit can be also enhanced by early planting, which enables early arrival of fruits into the markets at better prices for growers.

\section{Literature Cited}

Abak, K., H. Dasgan, O. Ikiz, and N. Uygun. 1997. Pollen production and quality of pepper grown in unheated greenhouses during winter and the effect of bumblebees (Bombus terrestris) pollination on fruit yield and quality. Acta Hort. 437:303-307.

Albano, S., E. Salvado, S. Duarte, A. Mexia, and P.A.V. Borges. 2009. Pollination effectiveness of different strawberry floral visitors in Ribatejo, Portugal: Selection of potential pollinators. Part 2. Adv. Hort. Sci. 23:246-253.

Ariza, M.T., C. Soria, J.J. Medina, and E. MartínezFerri. 2011. Fruit misshapen in strawberry 
cultivars (Fragaria $\times$ ananassa) is related to achenes functionality. Ann. Appl. Biol. 158: $130-138$.

CAP. 2007. Boletín de Información Agraria. 2007. Consejería de Agricultura y Pesca, Junta de Andalucía.

Carew, J.G., M. Morretini, and N.H. Battey. 2003. Misshapen fruits in strawberry. Small Fruit Rev. 2:37-50.

Chagnon, M., J. Gingras, and D. De Oliveira. 1993. Complementary aspects of strawberry pollination by honey and indigenous bees (Hymenoptera). J. Econ. Entomol. 86:416-420.

Del Pino, M. 1998. Evaluación de la actividad polinizadora de Bombus terrestris en tomate bajo invernadero. Influencia microclimática $\mathrm{y}$ ambiental. $\mathrm{PhD}$ thesis, Universidad de Almería.

Ercan, N. and A.N. Onus. 2003. The effects of bumblebees (Bombus terrestris L.) on fruit quality and yield of pepper (Capsicum annuиm L.) grown in an unheated greenhouse. Phytoparasitica 51:275-283.

Faedi, W. and G.L. Baruzzi. 2003. Strawberry production industry in the Mediterranean countries, p. 238-243. In: Childers, N.F. (ed.). The strawberry. A book for growers, others. Norman F. Childers Publications, University of Florida, Gainesville, FL.

FAOSTAT. 2008. FAOSTAT agricultural data. $<$ http://www.faostat.fao.org $>$.

García-Méndez, E., D. García-Sinovas, M.A. Andrade, B. González, J.J. Medina, L. Miranda, J.F. Sánchez-Sevilla, and J.M. López-Aranda. 2008. Influence of nitrogen fertilization and digging date on strawberry plant maturity. Acta Hort. 842:687-690.

Ito, H. and T. Saito. 1962. Studies on the flower formation in the strawberry plant. I. Effects of temperature and photoperiod on the flower formation. Tohoku J. Agr. Res. 13:191-203.

Kano, Y. and T. Asahira. 1981. Roles of cytokinin and abscisic acid in the maturing of strawberry fruits. J. Jpn. Soc. Hort. Sci. 50:31-36.

Kasperbauer, M.J. 2000. Strawberry yield over red versus black plastic mulch. Crop Sci. 40:171174.

Kronenberg, H.G. and L.M. Wassenaar. 1972. Dormancy and chilling requirements of strawberry varieties for early forcing. Euphytica 21:454 459.

Kumukara, H. and Y. Shishido. 1995. Effect of temperature and photoperiod on flower bud initiation in everbearing type strawberry cultivars. J. Jpn. Soc. Hort. Sci. 64:85-94.

Kwon, Y.J. and S. Saeed. 2003. Effect of temperature on the foraging activity of Bombus terrestris L. (Hymenoptera: Apidae) on greenhouse hot pepper (Capsicum annuum L.). Appl. Entomol. Zool. (Jpn.) 38:275-280.

Lamont, W. 2009. Overview of the use of high tunnels worldwide. HortTechnology 19 : 25-29.

Larson, K.D. 2001. El programa de investigación de fresa de la Universidad de California: Progreso y perspectiva, p. 14-17. In: Caja de Ahorros El Monte (ed.). XVIII Jornadas Agrícolas y Comerciales de El Monte, Ciudad Real.

Leech, L., D.W. Simpsom, and A. Whitehouse. 2000. Effect of temperature and relative humidity on pollen germination in four strawberry cultivars. Acta Hort. 567:261-263.

Lieten, F. 1997. Effects of chilling and night-break treatment on greenhouse production of 'Elsanta'. Acta Hort. 439:633-640.

López Aranda, J.M. 2008. The cultivation of the strawberry in Huelva, p. 101-174. In: Junta de Andalucía (ed.). The strawberry crop at Huelva. Ideas, Exclusivas y Publicidad S.L., Sevilla.

López-Aranda, J.M., J.J. Medina, J.I. Marsal, and R. Bartual. 2003. Strawberry production in Spain, p. 230-237. In: Childers, N.F. (ed.). The strawberry. A book for growers, others. Norman F. Childers Publications, University of Florida, Gainesville, FL.

López-Aranda, J.M., C. Soria, J.F. Sánchez-Sevilla, and J. Gálvez. 2005. 'Medina' strawberry. HortScience 40:482-483.

López-Medina, J., E. Vázquez, J.J. Medina, F. Domínguez, J.M. López-Aranda, R. Bartual, and F. Flores. 2001. Genotype $\times$ environment interaction for planting date and plant density effects on yield characters of strawberry. J. Hort. Sci. Biotechnol. 75:564-568.

Malagodi-Braga, K.S. 2002. Estudio de agentes polinizadores em cultura de morango (Fragaria $\times$ ananassa Duch.-Rosácea). PhD thesis, Instituto de Biociéncia, Sao Paulo, Brazil.
Malagodi-Braga, K.S. and A.M.P. Kleinert. 2004. Could Tetragonisca angustula Latreille (Apinae, Meliponini) be used as strawberry pollinator in greenhouses? Aust. J. Agr. Res. 55: 771-773.

Medina-Mínguez, J.J., L. Miranda, C. Soria, P. Palencia, and J.M. López-Aranda. 2009. Non-chemical alternatives to methyl bromide for strawberry: Biosolarization. A case-study in Huelva (Spain). Acta Hort. 842:961-964.

Paydas, S., S. Eti, O. Kaftanoglu, E. Yasa, and K. Derin. 2000. Effects of pollination of strawberry grown in plastic greenhouse by honeybees and bumblebees on the yield and quality of the fruits. Acta Hort. 513:443-452.

Perkins-Veazie, P. and D.J. Huber. 1987. Growth and ripening of strawberry fruit under field conditions. Annu. Meet. Fla. State Hort. Soc. 100:253-256.

Picken, A.J.F. 1984. A review of pollination and fruit set in the tomato (Lycopersicon esculentum Mill.). J. Amer. Soc. Hort. Sci. 59:1-13.

Roselino, A.C., S.B. Santos, M. Hrncir, and L.R. Bego. 2009. Differences between the quality of strawberries (Fragaria $\times$ ananassa) pollinated by the stingless bees Scaptotrigona aff. depilis and Nannotrigona testaceicornis. Genet. Mol. Res. 8:539-545.

Salamé-Donoso, T.P., B.M. Santos, C.K. Chandler, and S.A. Sargent. 2010. Effect of high tunnels on the growth, yields, and soluble solids of strawberry cultivars in Florida. Intl. J. Fruit Sci. 10:249-263.

Turemis, N., E. Ozdemir, and N. Kaska. 1996. Investigations on the effects of different plant distances on the runner production and quality of some important strawberry cvs. Bahçe 25:3-10.

Woon, K.K. and R.W. Michele. 1992. Lowtemperature injury to strawberry floral organs at several stages of development. HortScience 27:1302-1304.

Zaitoun, S.T., A.A. Al-Ghzawi, H.K. Shannag, A. Rahman, and R.M. Al-Tawahaa. 2006. Comparative study on the pollination of strawberry by bumble bees and honey bees under plastic house conditions in Jordan valley. J. Food Agr. Environ. 4:237-240. 